\section{Stomatal mechanism as the basis of evolution of crassulacean acid metabolism}

KEELEY et al. ${ }^{1}$ have demonstrated clearly that the rare pteridophyte, Stylites andicola (Isoetaceae), exhibits a variant of photosynthetic carbon metabolism which has obvious affinities with crassulacean acid metabolism (CAM). They also drew attention to the absence of stomata in Stylites and concluded that these findings taken together indicate that this unusual organism does not conform to the hypothesis that CAM may have evolved from stomatal guard cell metabolism ${ }^{2}$.

However, as other members of the Isoetaceae possess stomata, it may be that Stylites evolved from ancestors that did possess stomata and although it does not itself possess these structures, it may nevertheless use pathways derived from guard cell metabolism.

Thus the discovery of a CAM-like photosynthetic mechanism in $S$. andicola is not necessarily inconsistent with the evolution of CAM and associated pathways from stomatal guard cell metabolism.

\section{W. COCKBURN}

Department of Botany,

University of Leicester,

Leicester LEI 7RH, UK

1. Keeley, J. E., Osmond, C. B. \& Raven, J. A. Nature 310,
694-695 (1984). 2. Cockburn, W. Pl. Cell Envir. 4, 417-418 (1981)

THE suggestion by Keeley et al. ${ }^{\prime}$, supported by Moore ${ }^{2}$, that Stylites may represent an important link between aquatic plants and primitive land plants has little foundation in fact. To go further and propose that these plants could be relics of a marginally successful compromise from which present-day terrestrial photosynthetic systems were selected runs contrary to our views on plant evolution. Stylites, whose separation from Isoetes is questionable, is regarded generally as a descendant of a long line of lycophytes and should not be thought of as primitive plants. Specifically, they most probably evolved from woodystemmed plants with cormose bases, such as the Carboniferous swamp plant Chaloneria. These early lycophytes certainly possessed stomata ${ }^{3}$. Isoetes-like plants existed in the Triassic and probably spread along the coastal plains before moving inland. These are terrestrial species of Isoetes, shallow-water-living species (of which some have emergent sporophylls and others are totally submerged) and species living on the bottom of deep-water lakes. This migration into water resulted in the loss of stomatal function in shallow-water-living species (for example, Isoetes malinverneana) and the total loss of stomata in the deeper living species (for example, Isoetes lacustris) ${ }^{4}$.
The most plausible argument for Stylites not possessing stomata is that it lost them through submergence, not that its ancestors never possessed them.

It is true that in its type locality, Stylites grows above the water level, but plants have been found repeatedly that grow sub. merged. The lack of an efficient method of dispersal suggests that the plants have been growing in the same area for a very long time. The substantial elevation of the high Andes in relatively recent geological times could explain both their geographical isolation and the loss of their aquatic habitats.

The fact that both Stylites undergo CAM similar to the aquatic species of Isoetes is therefore not necessarily surprising. Stylites should not be thought of as evidence that CAM did not evolve from stomatal guard cell metabolism. It is more probable that its ability to convert to CAM as it invaded an aquatic environment saved it from extinction.

\section{B. A. Thomas}

Department of Life Sciences,

Goldsmiths' College,

University of London,

London SE14 6NW, UK

1. Keeley, J. E., Osmond, C. B. \& Raven, J. A. Nature 310 , 694-695 (1984)

2. Moore, P. D. Nature 310, 633 (1984)

3. Pigg, K. B. \& Rothwell, G. W. Bot. Gaz. 144, 132-142 (1983).

4. Masarati, D. L. \& Thomas, B. A. Phyta, 155-162 (1982).

KEELEY ET AL. REPLY-We agree with Cockburn that, although the presence of CAM in astomatous Stylites does not support his theory on the stomatal origin of CAM, it does not necessarily falsify the theory either.

We also agree with Thomas that Stylites most reasonably should be included with Isoetes, a taxon dating back only to the Triassic. Lycophytes, however, extend back to the Devonian. Although it has been proposed that Isoetes represents a reduction from a tree-like lycopod, it is clear that herbaceous lycophytes have been present since the Carboniferous and form the longest unbroken time record of any group of vascular plants ${ }^{1}$. We do not believe that Stylites (Isocetes) andicola was the first vascular land plant, but it may represent a model system for how vascular plants invaded seasonally dry terrestrial environments.

The view of the morphological evolution of Stylites which Thomas presents agrees with the known fossil record of the Isoetales (see Thomas and Brack-Hanes ${ }^{2}$ ). It is also consistent with two arguments proposed by Raven $^{3}$ as to the physiological significance of morphological attributes in vascular plants, the first of which relates to the presence of xylem tissue in Stylites. The probable earliest function for xylem was that of water conduction rather than mechanical support.
Transpiration does not necessarily imply the presence of stomata (compare with the extant Polytrichum and the SiluroDevonian Cooksonia), but it does indicate that a phototroph obtains $\mathrm{CO}_{2}$ from the air rather than the sediment. The second argument relates to the presence of intercellular air spaces which seem to be correlated with the presence, or occurrence at some stage in the plant's evolutionary history, of epidermal pores (Marchantiales) or stomata (sporophytes of vascular plants). These arguments suggest that Stylites was derived from transpiring ancestors that possessed stomata and derived $\mathrm{CO}_{2}$ from the atmosphere rather than the sediment. However, Raven ${ }^{3}$ noted that "the sequence of acquisition of $\mathrm{H}_{2} \mathrm{O}$. conducting and gas-exchange/regulation mechanisms revealed by the fossil record is generally in accord with teleological expectation, in that the $\mathrm{H}_{2} \mathrm{O}$-conducting system in the absence of the gasexchange/regulation mechanism would be of more selective advantage than the reverse state of affairs". Stylites may represent such a survivor.

Thomas' conjecture about the evolution of Stylites is not consistent with our observations. Although it is possible that Stylites 'lost' stomata, the argument proposed by Thomas is not plausible; he points out that deep-water Isoetes (for example, I. lacustris) have totally lost stomata and that the lack of stomata in Stylites may derive from a previous aquatic ancestry. Although aquatic Isoetes species from deep water are astomatous, all such species șo far tested (including $I$. macrospora, considered to be conspecific with I. lacustris ${ }^{4}$ ) will produce stomata on leaves initiated under 'artificial' aerial conditions (J.E.K., unpublished data).

The important feature of the astomatous habit of Stylites is the reliance on sediment carbon. Data on I. triquetra from the highaltitude paramo of the northern Andes (J.E.K., unpublished) and descriptions of the recently discovered $I$. hopei Croft from the topical alpine of New Guinea suggest that this syndrome, although rare, may be widespread globally in the Isoetaceae.

\section{J. E. KeELEy}

Department of Biology,

Occidental College,

Los Angeles,

California 90041, USA

Desert Research Institute,

University of Nevada,

Reno, Nevada 89506, USA

\section{J. A. RAVEN}

Department of Biological Sciences,

University of Dundee,

Dundee DDI $4 H N, U K$

1. Banks, H. P. BioScience 25, $730-737$ (1975)

2. Thomas, B. A. \& Brack-Hanes, S. D. Taxon 33, 247-255 (1984)

3. Raven, J. A. Bot, J. Linn. Soc. 88, 105-126 (1984).

4. Kott, L. \& Britton, D. M. Can. J. Bot. 61, 3140-3163 (1983). 